\title{
CONGENITAL MUSCULAR SQUINT
}

\author{
BY
}

LIONEL G. DODDS, O.B.E.

OPHTHALMIC SURGEON TO THE BRITISH HOSPITAL, BUENOS AIRES

THERE is a peculiar kind of squint, which is not concomitant, and has the following characteristic signs :

The movements of abduction of one or both eyes are either abolished or greatly reduced. The movements of adduction may be impaired or they may be normal; but they are always associated with a retraction of the eyeball into the orbit, and a closing of the palpebral fissure. The eye retracts more or less strongly into the orbit, and the palpebral fissure becomes narrower as the adduction of the eye increases.

This variety of squint is always congenital, as the acquired type, due to adhesions in the orbit, caused by cysts, inflammations, etc., and by cerebral disease, can scarcely be classified in this group.

A very complete study of this condition has been made by the late Professor Lagleyze of Buenos Aires, in his book Du Strabisme, published in Paris in 1913. He described five cases, two of which were limited to one eye, and the other three to both eyes. Other observers have studied this condition later, and Bietti was able to collect 31 cases published in ophthalmic literature. Duane published a record of 38 cases, of which 14 were his own. Since Lagleyze's time I have only seen one case, and Adrogué has collected seven cases seen at the Ophthalmic Hospital in Buenos Aires; some of his cases seem to be very doubtful and would be better diagnosed as absence of or congenital paralysis of the superior oblique, quite a different entity from the one under consideration.

In October, 1923, I was consulted by Robert S., an Argentine student, aged 16 years.

Examination.-Left eye convergent strabismus of $15^{\circ}$.

When made to look to the right, a deep retraction of the left eyeball into the orbit took place, and the palpebral fissure closed. The farther he looked to the right, the greater was the retraction and the narrower the palpebral fissure. When made to look to the left, the eye remained exactly in the middle line.

Diplopia did not exist in the primary position; but became manifest when the eyes were turned to the left.

Enophthalmos of a very slight degree existed in the left eye, whilst the palpebral fissure was narrower than that of the right eye. The measurements of the fissures were: R.E. $8 \mathrm{~mm}$.; L.E. $6 \mathrm{~mm}$.

In forced adduction the fissure was narrowed to $3 \mathrm{~mm}$. and there was a sinking of the eyeball into the orbit of about $5 \mathrm{~mm}$. 
In abduction the eye appeared to advance slightly.

The active movements of the left eye were: out $0^{\circ}$; in $10^{\circ}$; up $40^{\circ}$; down $40^{\circ}$.

The passive movements obtained by the use of fixation forceps were: out $5^{\circ}$; in $10^{\circ}$; up $40^{\circ}$; down $40^{\circ}$.

The movements of the right eye, active and passive, were quite normal.

Refraction examined with atropin. R.E. $+1.50 \mathrm{sph} .+2.50 \mathrm{cyl}$. axis $90^{\circ} ; \mathrm{V} .=6 / 9$. L.E. $+1.50 \mathrm{sph} .+2.50$ cyl axis $90^{\circ} ; \mathrm{V}:=$ $6 / 12$.

Diagnosis: Congenital muscular squint of the left eye.

Operation: Left eye, tenotomy internal rectus. The tendon and its insertion appeared to be normal; but on making traction upon it with the strabismus hook, it gave the impression of being a thick inextensible cord. The external rectus was not touched.

Result: The cosmetic effect of the operation was good and satisfied the patient. The retraction of the eyeball which existed in the primary position disappeared; the lateral movements of the eye were unchanged, and the retraction on forced adduction still persisted. The palpebral opening was widened and appeared to be more or less the size of the right one.

\section{Pathogenesis}

The exact cause of this variety of strabismus is still unknown, and its two characteristic symptoms must be studied separately.

The absence of the movements of abduction is not due to a paralysis of the external rectus, because even with a fixation forceps, the eye cannot be drawn out ; nor is it due to the congenital absence of the muscle, because I have been able to detect muscular fibres in two of the cases that Lagleyze operated on and Adrogué has also noted their presence in cases operated upon by him.

The retraction of the eyeball into the orbit is not easily explained. Certain mammals have a retracting muscle which pulls the eye back; but it has never been found in man. Some observers, such as Axenfeld, consider the retraction to be due to an inextensible ligament, which is inserted behind to the orbital wall, and extends forward to the eyeball, fixing it in a certain position and impeding the action of the muscles, although they may be quite normal. Lagleyze searched very carefully for this ligament and was not able to find it in any of the cases operated upon by him.

Other observers consider it to be due to a very short and powerful internal rectus, inserted near the posterior pole of the eye; but I have not found this to be so, as in the case I operated upon, though the tendon was very stout, it was inserted in its usual place.

Histological changes exist in the muscles and in the aponeuroses. There must be an abnormal formation of fibrous tissue in the 
muscles and a thickening of the aponeuroses, which either abolishes or greatly diminishes muscular contractility. Most of the symptoms observed in this variety of squint, could be explained by the formation of fibrous tissue. The diminished lateral movements of the eye, by the absence of muscular contractility; and the retraction of the eyeball, by the shrinking inherent to all fibrous tissue, and consequently to the shortening of the internal rectus, and the loss of elasticity of the external rectus.

The literature on the pathology of this disease is abundant; but the conclusions of Alling, Green, Türk and Bahr are unsatisfactory.

The condition of the sclerotic in all cases of congenital strabismus is interesting. Schoeller remarked that it was extremely thin ; and in eight cases operated upon by him, he had three cases of perforation during tenotomy or advancement; and this was in no way attributable to faulty technique as in over 2,000 operations for ordinary squint, this accident never occurred. Both Axenfeld and Lagleyze have had similar accidents. In the latter's case he was demonstrating to the students the great resistance offered by the internal rectus, by making traction upon it with a strabismus hook, when he was disagreeably surprised to find that the sclerotic had given way just beneath the insertion of the muscle. On examination of the sclerotic it was found to be very thin and of a pale blue colour.

\section{BIBLIOGRAPHY.}

Hench.-Klin. Monatsbl. f. Augenheilk., 1876.

Türk.-Ueber Retraktion Bewegungen der Augen. Deutsch. Med. Wochenschr., 1896.

Wolf.-Arch.f. Augenheilk., Vol. XLIV.

Evans.-Congenital defect of abduction associated with retraction of the eyeball in adduction. Ophthal. Rev., Vol. XXII, January, 1903.

Schoeller.-Ueber die Schiel-Operation bei angeborener Lähmung des Musculus rectus externus. Berl. Klin. Wochenschr., No. 33, 1902.

Lagleyze.-Du strabisme. 1913.

Bietti.-Sui movimenti di retrazione dell occhio. Ann. di Ottal., Vol. XXXII, p. 264.

Duane.-Arch. of Ophthal., Vol. XXXIV, No. 2.

Adrogué. - Semana Médica, No. 26, 1925.

Willbrand and Saenger.--Neurology of the Eyes. Vol. VIII, 1921.

\section{ANNOTATION}

\section{Institutional Treatment of Eye Disease in Children}

In the treatment of interstitial keratitis the benefit of any special measures may be open to discussion. There can, however, be no doubt as to the necessity for seeing that the patient is placed under the best hygienic conditions. Even if these were obtainable in our Metropolitan Hospitals the pressure on the available accommodation would prevent their use for such a chronic complaint. 